\title{
Morphometric and Change Detection Analysis for Prioritization of Sub Basin Conservation, Case Study of Taita Hills
}

\author{
Mark Boitt*, Nyamwamu Bebeto \\ Department of Geomatic Engineering and Geospatial Information Systems, Jomo Kenyattta University of Agriculture and \\ Technology, Juja, Kenya \\ Email:*mboitt@.jkuat.ac.ke
}

How to cite this paper: Boitt, M. and Bebeto, N. (2020) Morphometric and Change Detection Analysis for Prioritization of Sub Basin Conservation, Case Study of Taita Hills. International Journal of Geosciences, 11, 591-612.

https://doi.org/10.4236/ijg.2020.1110031

Received: July 24, 2020

Accepted: October 26, 2020

Published: October 29, 2020

Copyright $\odot 2020$ by author(s) and Scientific Research Publishing Inc. This work is licensed under the Creative Commons Attribution International License (CC BY 4.0).

http://creativecommons.org/licenses/by/4.0/

\begin{abstract}
The study is aimed at analyzing the risk of Taita Hills region of harmful runoff and soil erosion by employing morphometric analysis and change detection in a GIS environment to prioritize the Taita Hills in Taita Taveta County. The objective of the study was to characterize and give hierarchy in which the region should be conserved. The methodology adopted hydrological modeling, morphometric computation, Weighted Sum Analysis (WSA) and change detection. Hydrological modeling was vital in delineating the sub-watersheds and stream network. Morphometric computation and WSA was applicable in coming up with parameters and weighting the parameters for each sub-watershed's prioritization. Change detection is related to how human activity is important for conservation as the effect of land forms and dimensions are compounded. Twenty-one fourth order streamed sub-watersheds were generated and prioritized using morphometry and change detection. Every sub-watershed is given a hierarchy based on the calculated compound parameter from the WSA equation developed and shows the risk of runoff and soil erosion. The morphometric prioritization shows $47 \%$ of the watersheds are in the high and very highly susceptible areas and there are two sub-watersheds with the highest land cover change. As well six sub-watersheds are risky with both land cover change and morphometry.
\end{abstract}

\section{Keywords}

Watershed Prioritization, Morphometric Analysis, GIS, Change Detection

\section{Introduction}

The level of urbanization and deforestation within and around Taita Hills has 
led to continuous changes to destruction of the watershed environment within Taita Hills. The region surrounding Taita Hills is home to wild animals that depend on the river basin for continuous supply of food and water. As well the humans living around Wundanyi depend on the river basin for the environment's suitability to grow food and water. With increased population and thus deforestation for agriculture and urbanization there is a strain on the water tower (Taita Hills).

The ongoing reduction of the Taita Hills forest coverage affects the sustainable supply of the natural and conducive environment for water cycle regeneration and growth of food for humans and animals. The result is the drying of rivers and loss of biodiversity. According to [1], there is increased population growth and continuous demand for food production. For this reason, people have turned to forest and rangeland ecosystems that are water towers with favorable areas for agriculture thus increasing pressure on water resources and soil.

Considering the current levels of degradation of the river basins and its environs, there is a need for responsible and sustainable management within the spatial extents of the micro-environments. For sustainable management of the biodiversity, it is only imperative to show the trends of degradation of the river basins, analyze the factors and provide restoration measures.

Now in areas like Taita Hills that has 3 competing elements; urbanization, agriculture and wildlife, there is a need to discriminate the effects of the factors of degradation of the river basin environment. With known trends of degradation then it is possible to improve and provide conservation and restoration efforts where they are needed.

In this study, geographical information system (GIS) technology and Remote Sensing will be used to map, analyze using morphometry and land use and prioritize for conservation regions of river basin degradation in Taita Hills. Therefore, the main objective of this study research was to characterize and prioritize Taita Hills water catchment through in-depth terrain evaluation together with change detection to look into conservation goals.

\section{Materials and Methods}

\subsection{Study Area}

The Taita Hills catchment is located between $38^{\circ} 10^{\prime} 58^{\prime \prime} \mathrm{E}$ to $38^{\circ} 33^{\prime} 29^{\prime \prime} \mathrm{E}$ longitude and $3^{\circ} 14^{\prime} 51 \mathrm{~S}$ to $3^{\circ} 31^{\prime} 6^{\prime \prime S}$ latitude in Taita Taveta County and the major river in the catchment is River Voi. The shape of Taita Hills watershed is nearly rectangular and has an area of $1391.45 \mathrm{~km}^{2}$ with $483 \mathrm{~m}$ minimum and $2467 \mathrm{~m}$ maximum elevations. The catchment has the highest rainfall in months around April and November and lowest rainfall in months around July with average annual rainfall being about $1100 \mathrm{~mm}$. The area has an annual average temperature of $23^{\circ}$. The area has previously been mostly forestland but with urbanization, agricultural and urban use has grown significantly. 


\subsection{Data and Methodology}

The data used in this research was satellite data. Both the DEM and satellite images are satellite data. The DEM of 30 by $30 \mathrm{~m}$ of the SRTM archive was used to delineate watersheds and the stream network. The satellite images from Landsat 7 (2001) and Landsat 8 (2017) were used to do change detection. The study followed the following flow of steps (See Figure 1).

\subsection{Morphometric Analysis and Prioritization}

According to [2] degradation is the decrease of resource potential of the natural landscape by different processes. The resource potential includes plant life, soil and (or) water. Therefore, even the altering of the water cycle falls as degradation.

The processes that promote degradation are assumed to be by humans and animals through over-use and climate variability in accelerated loop process. The accelerated loop process is accelerated by the net removal of plant cover by humans, animals and (or) together with the climate [3].

Conservation efforts are mainly done by public institutions and NGOs to maintain the natural environment and attain sustainability from the resources of the environment.

According to the UN [4], natural and indigenous environments are under threat of destruction. More so, the areas affected are water catchment areas that provide $80 \%$ of earth's fresh water supply. In all efforts to protect such environments, parties have looked at human activities only with less concentration of the extensive terrain and its effects.

Forest areas in Kenya still serve a big contribution in the provision of clean water for use. As well there are effects of soil erosion and water runoff that contribute in the instability of such important environments. For efficient conservation minus human activities, morphometry is important in identifying region that requires extra protection.

Being the description of the land features and the terrain, hydrology analysis is the primary process. Hydrology analysis involves stream network and watersheds generation. From the stream network, stream ordering is the next process denoting the hierarchy and arrangement of rivers in a study area.

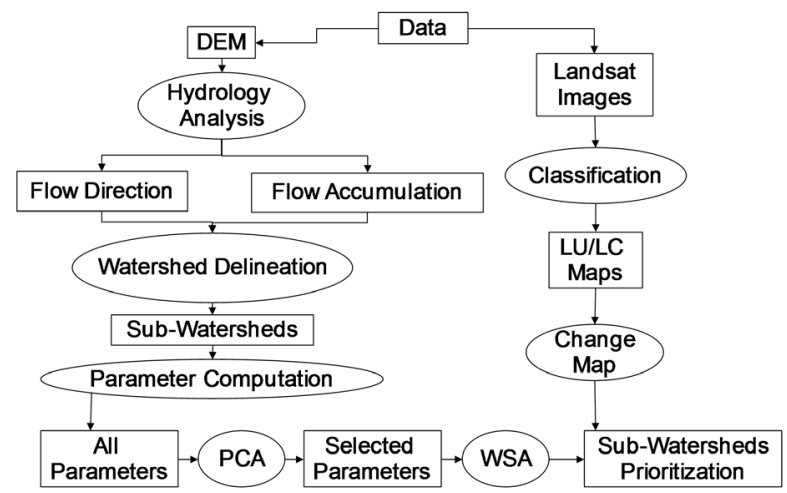

Figure 1. Methodology flowchart. 
According to [5] the Arc Hydro tools are used in the hydrological analysis of the region. The study lists the following steps in the process of hydrology analysis:

1) Generation of a DEM without sinks.

2) Developing Flow Direction to give the direction of runoff flow.

3) Developing of Flow Accumulation to highlight the stream channels.

4) Flow Accumulation is then used to give pour points. Pour points are significant locations that show the highest flow accumulation within the region.

5) The pour points are then located and used to delineate sub watersheds served by the pour points.

6) From the Flow Accumulation streams are assigned orders using.

The Arc Hydro toolset is used as it is more objective and consistent as compared to the manual approaches. Now from this drainage generation process, we get sub watersheds, streams, and stream orders (using [6] ordering).

Morphometric analysis is performed by measurement of linear, areal and shape parameters. According to [7] and [8] they document that the various parameters have varying effects on soil erosion and water runoff.

In their various definitions the morphometric parameters are:

\section{1) Bifurcation Ratio}

The bifurcation ratio is the ratio of the number of the stream segments of given order to the number of streams in the next higher order [9]. The Bifurcation ratio can be used as an indicator of relief and dissection. A study by [6] shows that bifurcation ratio shows slight variations according to environment and regions. It is given by;

$$
\mathrm{Rb}=\mathrm{Nu} / \mathrm{Nu}+1
$$

\section{2) Drainage Density}

Drainage density is defined as the measure of the texture of the drainage basin. Drainage density is the ratio of the total stream length $(\mathrm{Lu})$ cumulated to all orders in the basin to the total basin area (A).

$$
\mathrm{Dd}=\mathrm{Lu} / \mathrm{A}
$$

Low density shows highly resistant subsoil material under dense vegetation and low relief or highly permeable whereas high density shows impermeable soft material or weak rock. Drainage density is important in the sense that it indicates linear scale of landform element in stream eroded topography, defines the total length of the stream and closeness of spacing.

\section{3) Stream Frequency}

The drainage frequency introduced by [10] is the stream frequency or channel frequency as the number of stream segments $(\mathrm{Nu})$ per unit area (A). Given by;

$$
\mathrm{Fs}=\mathrm{Nu} / \mathrm{A}
$$

Basically, stream frequency shows the correlation between stream population and drainage density and is affected by temperature and rainfall.

\section{4) Drainage Texture}

\section{Given by;}




$$
\mathrm{Dt}=\mathrm{Nu} / \mathrm{P}
$$

Drainage texture (Dt) is the total number of stream segments of all orders per perimeter of that area [9]. It is a measure of relief aspect, rainfall, lithology, vegetation, infiltration capacity, of the terrain and closeness of channel spacing.

\section{5) Form Factor}

The form factor (Ff) is defined as the ratio of basin area to the square of the basin length and is a quantitative expression of drainage basin outline. It indicates the flow intensity of a basin of a defined area [9].

$$
\mathrm{Ff}=\mathrm{A} / \mathrm{Lb}^{2}
$$

The value ranges from 0 - 1 for highly elongated basic to a highly circular basin respectively. Form factors form a good indicator to the management of flood flows.

\section{6) Circulatory Ratio}

Also known as the compactness ratio the circulatory ratio is defined as the ratio of the area of the basin (A) to the area of the circle having the same circumference as the perimeter $(\mathrm{P})$ of the basin [11].

$$
\mathrm{Rc}=12.57 \times \mathrm{A} / \mathrm{P}^{2}
$$

The lithological characteristics of the basin have the most impact on the compactness ratio as compared to any other factor. It is important in staging of the streams as young, mature or old.

\section{7) Elongation Ratio}

Elongation ratio is defined as the ratio between the diameter of a circle of the same area as the drainage basin and the maximum length of the basin [12]. The elongation ratio is a pointer of the relief and the slope of the slope. It is calculated by;

$$
\operatorname{Re}=2 / \mathrm{Lb} \times(\mathrm{A} / \pi) 0.5
$$

\section{8) Length of Over Land Flow}

The length of overland flow is the length of water over the ground surface before it gets concentrated into definite stream channel [9].

The length is given by the formula;

$$
\operatorname{Lg}=\mathrm{A} / 2 \times \mathrm{L}
$$

The length of Over land flow is an important variable of physiographic development and hydrologic of drainage basin. The length of overland flow differentiates between sheet erosion and channel erosion as defined by [9].

\section{9) Shape Factor}

The shape of the basin can be described qualitatively or quantitatively. The qualitative description uses the terms rectangular, triangular, pear and circular to describe the shape. Quantitatively, the basin shape is described using the shape factor that is calculated by;

$$
\mathrm{BSF}=\mathrm{L}^{2} / \mathrm{A}=\mathrm{L} / \mathrm{W}
$$

Shape determines peak discharge and arrival at the basin. 


\section{0) Relief Ratio}

Relief ratio is a gradient measure depicting the mouth of a basin and its highest point [12].

$$
\mathrm{Rh}=\mathrm{Bh} / \mathrm{Lb}
$$

\section{1) Ruggedness Number}

Ruggedness number indicates the structural complexity of the terrain. An extremely high value of ruggedness number occurs when both variables i.e. drainage density and relief are high and slope is not only steep but long as well [6].

$$
\mathrm{Rn}=\mathrm{Bh} \times \mathrm{Dd}
$$

The number is a good indicator of soil erosion and intrinsic structural complexity in relation to relief and slope.

\section{2) Compactness Constant}

The term Compactness coefficient majorly used to describe the compactness constant. The compactness coefficient is the ratio of perimeter of sub-basin to circumference of circular area [13].

$$
\mathrm{Cc}=0.2841 \times \mathrm{P} / \mathrm{A} 0.5
$$

The compactness constant is only dependent on slope and not the size. This means a perfectly circular sub-basin will give a constant of 1 regardless of the size [13].

\section{3) Basin Relief}

Total basin relief is the maximum vertical distance between the lowest and the highest points in a basin [9] [14]. It is a factor in determining the denudational characteristic of a basin.

$$
\mathrm{Bh}=\mathrm{H}-\mathrm{h}
$$

The Morphometric analysis begins with computation of the parameters of all sub-watersheds using the already established formulas the parameters are computed as listed in Table 1.

From past studies, the parameters used occur as the major ones with significant effect on the surface flows and soil erosion. They are a number and it is a rigor to use all of them in the visualization of the surface characteristics. Thus, the need for selection of parameters is that best represent the others.

Looking at the number of morphometric parameters (13) that have been computed, some of them share characteristics and effects on soil erosion and runoff. Therefore, there's the need to remove redundant parameters and remain with parameters that exhibit the strongest characteristics required for prioritization.

The technique used for selection of parameters is Principal Component Analysis (PCA). As much as it has been used to process satellite images for a few bands, it is a statistical method used for various purposes. PCA as described by [1] is a method for exploratory analysis and in this study PCA was vital in evaluating the most valuable parameters from the 13 that still give the best representation of the dataset. Also, the 13 parameters share similar effects on runoff 
Table 1. Morphometric parameter formulas.

\begin{tabular}{|c|c|c|}
\hline Parameter & Formula & Reference \\
\hline Bifurcation Ratio (Rb) & $\begin{array}{l}\mathrm{Rb}=\mathrm{Nu} / \mathrm{Nu}+1 \text { where, } \\
\mathrm{Nu}=\text { Total number of stream segment of order " } \mathrm{u} \text { "; } \\
\mathrm{Nu}+1=\text { Number of segments of next higher order }\end{array}$ & [6] [9] \\
\hline Drainage Density (Dd) & $\begin{array}{c}\mathrm{Dd}=\mathrm{Lu} / \mathrm{A} \text { where, } \mathrm{Lu}=\text { Total length of streams; } \\
\qquad \mathrm{A}=\text { Area of watershed }\end{array}$ & [9] \\
\hline Stream Frequency (Fs) & $\begin{array}{c}\text { Fs }=\text { N/A where }, N=\text { Total number of streams; } \\
\qquad A=\text { Area of watershed }\end{array}$ & {$[10]$} \\
\hline Drainage Texture (Dt) & $\begin{array}{c}\mathrm{T}=\mathrm{Nu} / \mathrm{P} \text { where, } \mathrm{Nu}=\text { Total no of streams of order "u"; } \\
\mathrm{P}=\text { Perimeter of watershed }\end{array}$ & [9] \\
\hline Form Factor ( $\mathrm{Rf}$ ) & $\begin{array}{c}\mathrm{Rf}=\mathrm{A} / \mathrm{Lb}^{2} \text { where, } \mathrm{A}=\text { Area of watershed, } \\
\mathrm{Lb}=\text { Basin length }\end{array}$ & [9] \\
\hline Circulatory Ratio (Rc) & $\begin{array}{c}\mathrm{Rc}=4 \pi \mathrm{A} / \mathrm{P}^{2} \text { where, } \mathrm{A}=\text { Area of watershed } \\
\pi=3.14, \mathrm{P}=\text { Perimeter of watershed }\end{array}$ & [11] \\
\hline Elongation Ratio (Re) & $\begin{array}{c}\operatorname{Re}=2 \sqrt{ }(\mathrm{A} / \pi)^{*} \mathrm{Lb} \text { where, } \mathrm{A}=\text { Area of watershed, } \\
\pi=3.14, \mathrm{Lb}=\text { Basin length }\end{array}$ & {$[12]$} \\
\hline $\begin{array}{l}\text { Length of Over Land Flow } \\
\text { (Lof) }\end{array}$ & $\begin{array}{c}\text { Lof }=1 / 2 \text { Dd where, } \\
\operatorname{Dd}=\text { Drainage density }\end{array}$ & [9] \\
\hline Shape Factor (Bs) & $\begin{array}{c}\mathrm{Bs}=\mathrm{Lb}^{2} / \mathrm{A} \text { where, } \mathrm{Lb}=\text { Basin length, } \\
\qquad \mathrm{A}=\text { Area of basin }\end{array}$ & {$[11]$} \\
\hline Relief Ratio (Rh) & $\begin{array}{c}\mathrm{Rh}=\mathrm{Bh} / \mathrm{Lb} \text { where, } \mathrm{Bh}=\text { Basin relief, } \\
\mathrm{Lb}=\text { Basin length }\end{array}$ & [14] \\
\hline Ruggedness Number (Rn) & $\begin{array}{c}\mathrm{Rn}=\mathrm{Bh}^{\star} \mathrm{Dd} \text { where }, \mathrm{Bh}=\text { basin Relief, } \\
\mathrm{Dd}=\text { Drainage Density }\end{array}$ & [6] \\
\hline $\begin{array}{l}\text { Compactness Coefficient } \\
\text { (Cc) }\end{array}$ & $\begin{array}{c}\mathrm{Cc}=0.2821 \mathrm{P} / \mathrm{A} 0.5 \text { where } \\
\mathrm{P}=\text { Perimeter of watershed, } \mathrm{A}=\text { Area of watershed }\end{array}$ & [13] \\
\hline Basin Relief (Bh) & $\begin{array}{c}\mathrm{Bh}=\mathrm{H}-\mathrm{h} \text { where } \mathrm{H}=\text { Highest elevation, } \\
\mathrm{h}=\text { lowest elevation of the basin }\end{array}$ & [6] \\
\hline
\end{tabular}

and soil erosion, therefore there is the need to use the fewest possible parameters to evaluate the risk for ease in visualization. The PCA was run in an R environment and the computed morphometric parameters were loaded and the outputs were variances for all the principle components. From which only 6 components of the total are selected as they explain 99.4 (0.994) of the total data (Table 2) through the cumulative proportion variances. The PCA through the use of the variances and Eigen values (Table 3) selected the Bifurcation Ratio, Stream Frequency, Drainage Density, Drainage Texture, Length of Over Land Flow, and Circulatory Ratio as the best 6 parameters matching the principal components to represent all the parameters. 
Table 2. PCA results for the influential 6 components.

\begin{tabular}{ccccccc}
\hline & PC1 & PC2 & PC3 & PC4 & PC5 & PC6 \\
\hline Standard deviation & 2.177 & 1.874 & 1.435 & 1.082 & 0.931 & 0.759 \\
Proportion of Variance & 0.364 & 0.206 & 0.157 & 0.097 & 0.068 & 0.062 \\
Cumulative Proportion & 0.365 & 0.635 & 0.793 & 0.883 & 0.950 & 0.994 \\
\hline
\end{tabular}

Table 3. PCA eigen values.

\begin{tabular}{ccccccc}
\hline & PC1 & PC2 & PC3 & PC4 & PC5 & PC6 \\
\hline Lof & 0.1463 & -0.0772 & 0.2066 & 0.1032 & 0.9304 & -0.2137 \\
Dt & -0.0938 & -0.1439 & 0.2534 & 0.7413 & -0.1824 & -0.3620 \\
Rc & -0.2038 & 0.3958 & 0.2187 & 0.1832 & 0.0962 & $\mathbf{0 . 4 3 4 3}$ \\
Rn & 0.3719 & -0.0676 & 0.1727 & 0.4260 & -0.1935 & 0.0851 \\
Re & -0.2033 & 0.3945 & 0.2212 & 0.1838 & 0.0992 & 0.4312 \\
Cc & 0.2985 & -0.0748 & -0.4326 & 0.2633 & 0.0950 & 0.3689 \\
Rf & -0.4072 & -0.0936 & -0.2636 & 0.1503 & 0.0548 & -0.0102 \\
Rbm & $\mathbf{0 . 4 1 4 5}$ & 0.0744 & 0.2578 & -0.1311 & -0.0941 & 0.0340 \\
Dd & -0.2987 & 0.1256 & 0.4466 & -0.2087 & -0.1184 & -0.2681 \\
Bs & 0.4134 & 0.0790 & 0.2597 & -0.1361 & -0.0852 & 0.0280 \\
Bh & 0.2255 & 0.4252 & -0.1767 & -0.0150 & -0.0424 & -0.3000 \\
Rh & -0.0157 & 0.4161 & -0.3765 & 0.1229 & 0.0201 & -0.3427 \\
Fs & 0.1032 & $\mathbf{0 . 5 1 0 5}$ & -0.0602 & 0.0668 & 0.0114 & -0.1550 \\
\hline
\end{tabular}

From the having the best parameters to use, then comes the need to visualize the combined effect of the parameters for use in prioritization. To achieve prioritization, Multi criteria Decision Making (MCDM) is important to make complex decisions that are special in nature like allocating varied efforts for conservation goals.

Several studies have used MCDM techniques to prioritize watersheds for conservation. Prioritization is an important process which highlights the hierarchy in which region is to receive varied treatment. According to [15] Weighted Sum Analysis (WSA) is highly suitable and efficient for MCDM as hard to obtain expert opinions are limited as required in AHP, a better MCDM technique.

Both [15] and [7] show the ranking of watersheds in the different selected parameters with already established patterns how the parameters affect soil erosion and runoff. In both studies geomorphometric parameters are ranked, correlation done, and weights generated to show their importance. Ranking looks at the relation of the individual parameters to the soil erosion and runoff. For instance, if 
parameter A follows the general rule of being directly proportional to runoff, then the sub-watershed with the lowest will be assigned 1 increasing to the highest rank, or if parameter A follows the general rule of indirectly proportional to runoff, then the sub-watershed with the highest will be assigned 1 increasing to the highest rank. Table 3 shows a correlation matrix developed to help in the weighting of the parameters.

The weights are important in coming up with a Compound parameter for each sub-watershed highlighting the risk. From Table 2 we obtain the equation:

$$
\begin{aligned}
\mathrm{CP}= & (0.1095 \times \mathrm{Rbm})+(0.2004 \times \mathrm{Fs})+(0.2540 \times \mathrm{Dd}) \\
& +(0.0289 \times \mathrm{Dt})+(0.2540 \times \mathrm{Lof})+(0.1531 \times \mathrm{Rc})
\end{aligned}
$$

where $\mathrm{CP}$ is the Compound Parameter

$\mathrm{Rbm}$ is the Bifurcation Ratio

Fs is the Stream Frequency

Dd is Drainage Density

Dt is Drainage Texture

Lof is Length of Over Land Glow

Rc is Circulatory Ratio

\subsection{Change Detection}

The study of environmental degradation has often looked at the human activities that happen on the earth surface. As much as the human activities contribute significantly to loss of the natural biodiversity, there is a factor that has mostly been sidelined which is morphometry.

Landform processes and erosional characteristics that are statistically represented constitute morphometry and are substantial in describing the peculiarity of sub-watersheds through morphometric parameters. [16]

Even with the connection of morphometry and land use-land cover (LU/LC), [17] tries to give some better characterization of watershed by superimposing of the morphometric parameters and LU/LC layers.

The study followed through:

Image Processing: this process involved two satellite imagery; Landsat 7 (2001) and Landsat 8 (2017). ArcGIS was used in processing of the images.

Landsat 7 and 8: these are medium resolution multi-spectral sensors used mainly for land cover monitoring and environmental monitoring. Only one scene was downloaded and used from the respective sensors' archives. The true color composites were used by layer stacking the respective 3 bands out of the 12 spectral bands. Bands 1, 2, and 3 and bands 2, 3, and 4 were used for Landsat 7 and 8 respectively to obtain images of $30 \mathrm{~m}$ spatial resolution. The images were pan-sharpened using the Pan band from the respective band set to obtain 2 images of $15 \mathrm{~m}$ resolution. A subset of the area of interest (AOI) i.e. Taita Hills Region was obtained from the pan-sharpened true composite images.

Classification: Supervised classification using Maximum Likelihood technique was carried out on the masked Landsat images where the following land 
cover classes were used; Forest, Cropland, Settlement, Shrub-Grassland and Rock Surface.

Change Detection: This was done to highlight the areas with the highest harmful land cover changes. The change detection was performed by converting the raster classified images into vector. Then the ArcGIS intersect tool was used to create overlapping land covers from the 2 images giving all the changes. The resulting vector data of change detection is then looked at from the point of forest and cropland to other land covers as vital cases for conservation.

\section{Results}

Hydrology analysis resulted in stream network making the study area a 4-order area and the 21 sub watersheds.

Table 4 shows all the 13 morphometric parameters with the basic ones that are inputs in the PCA and WSA.

Figure 2 is a Flow accumulation map which gives the highlight of the river network: from which sub-watersheds are also generated.

Figures 3-8 are maps for the six selected parameters that were used in prioritization and how they vary for the sub-watersheds:

Table 5 shows the Compound Parameters for the sub-watersheds highlighting the prioritization of the sub-watersheds.

Figure 9 is a spatial representation of the prioritization after WSA on the 6 selected parameters inclusive of the stream network and it's ordering.

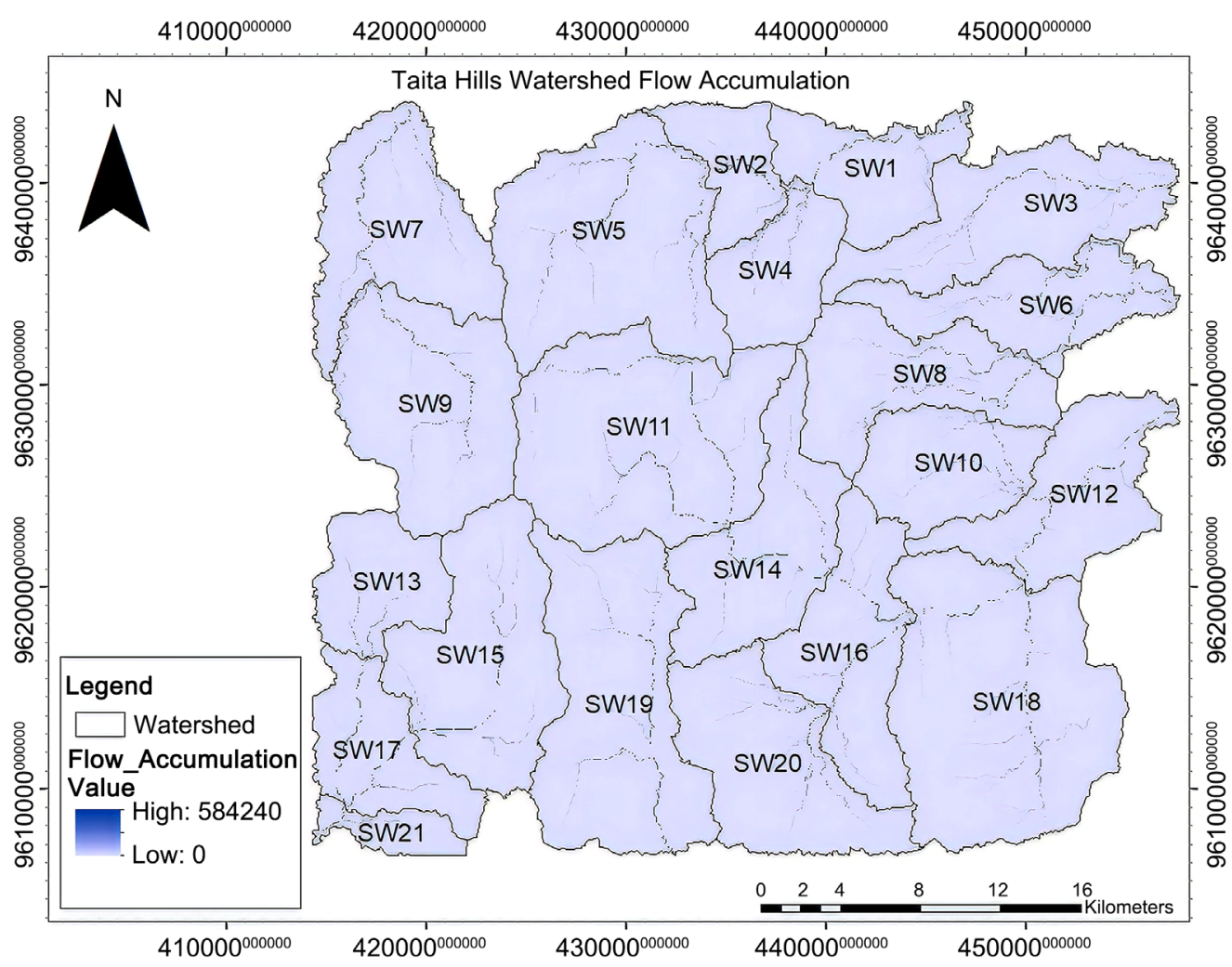

Figure 2. Sub-watersheds and flow accumulation. 


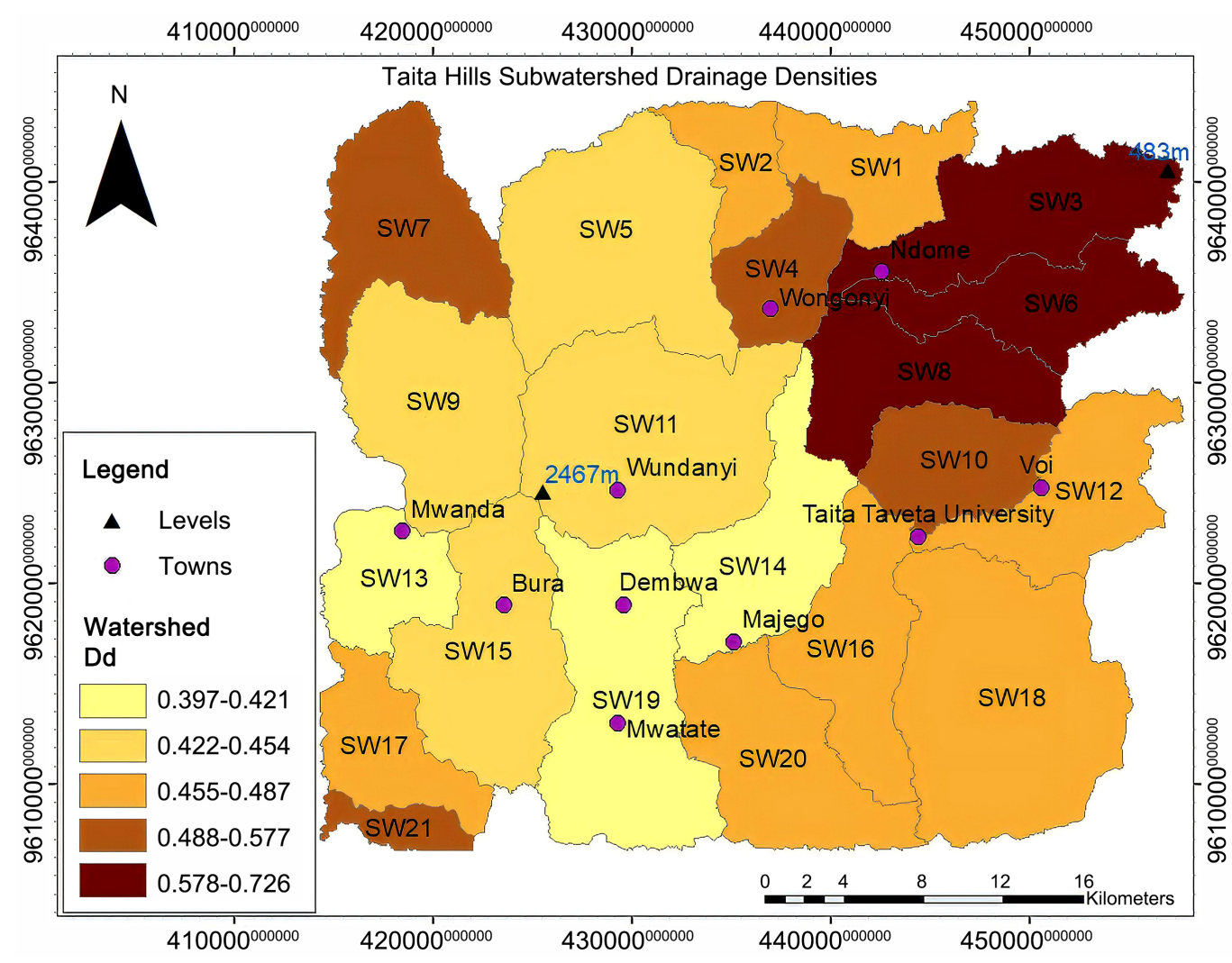

Figure 3. Drainage densities.

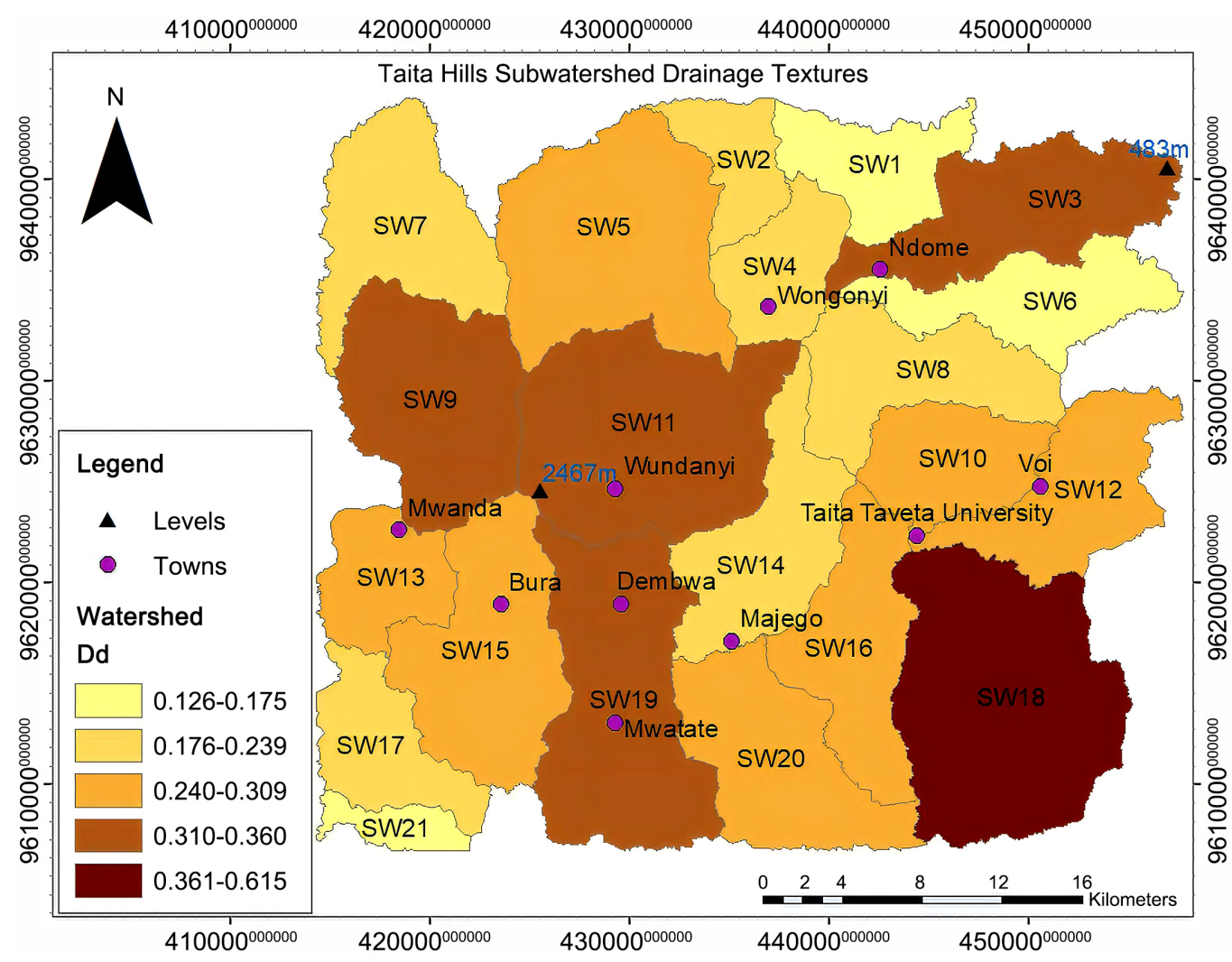

Figure 4. Drainage textures. 


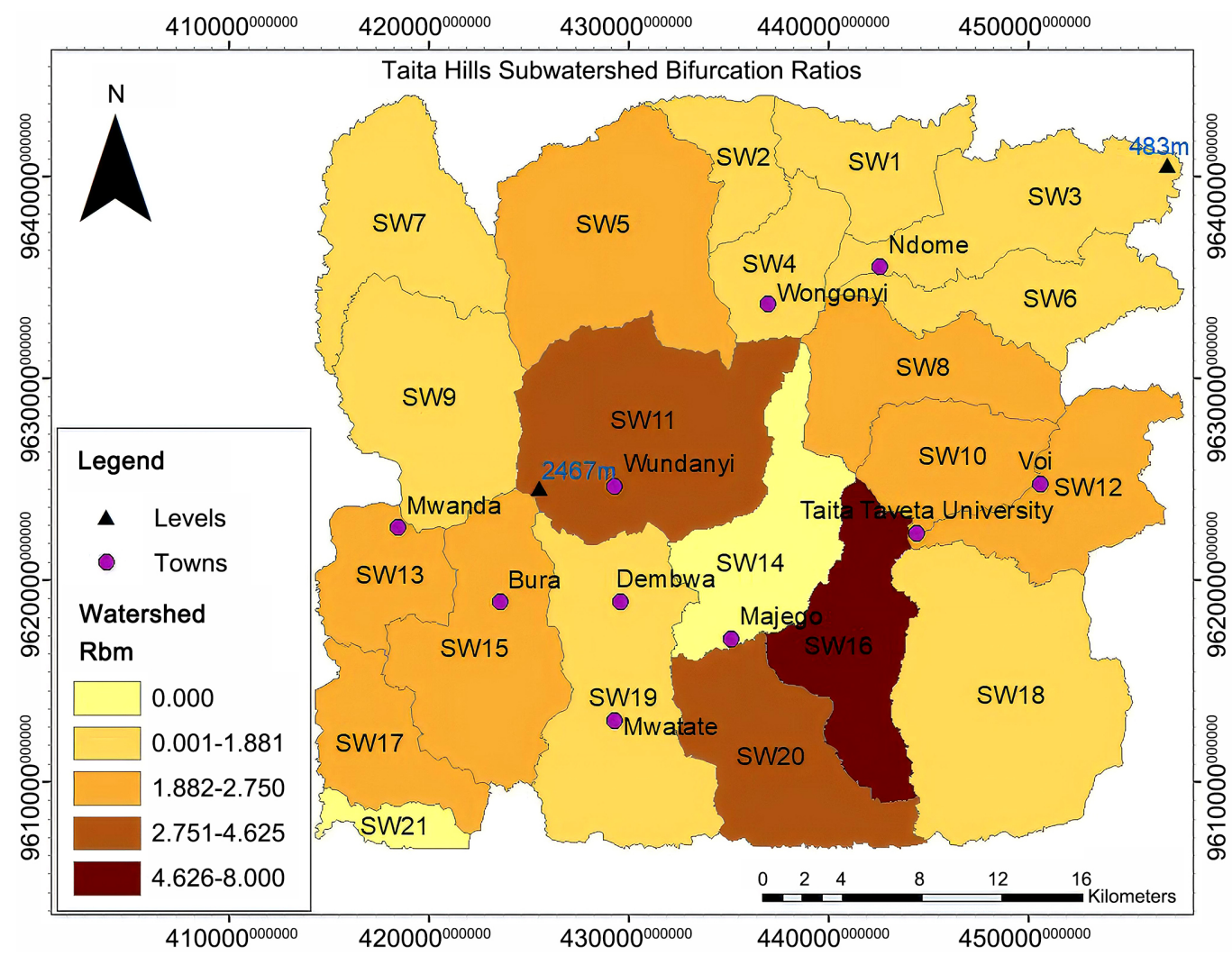

Figure 5. Bifurcation ratios.

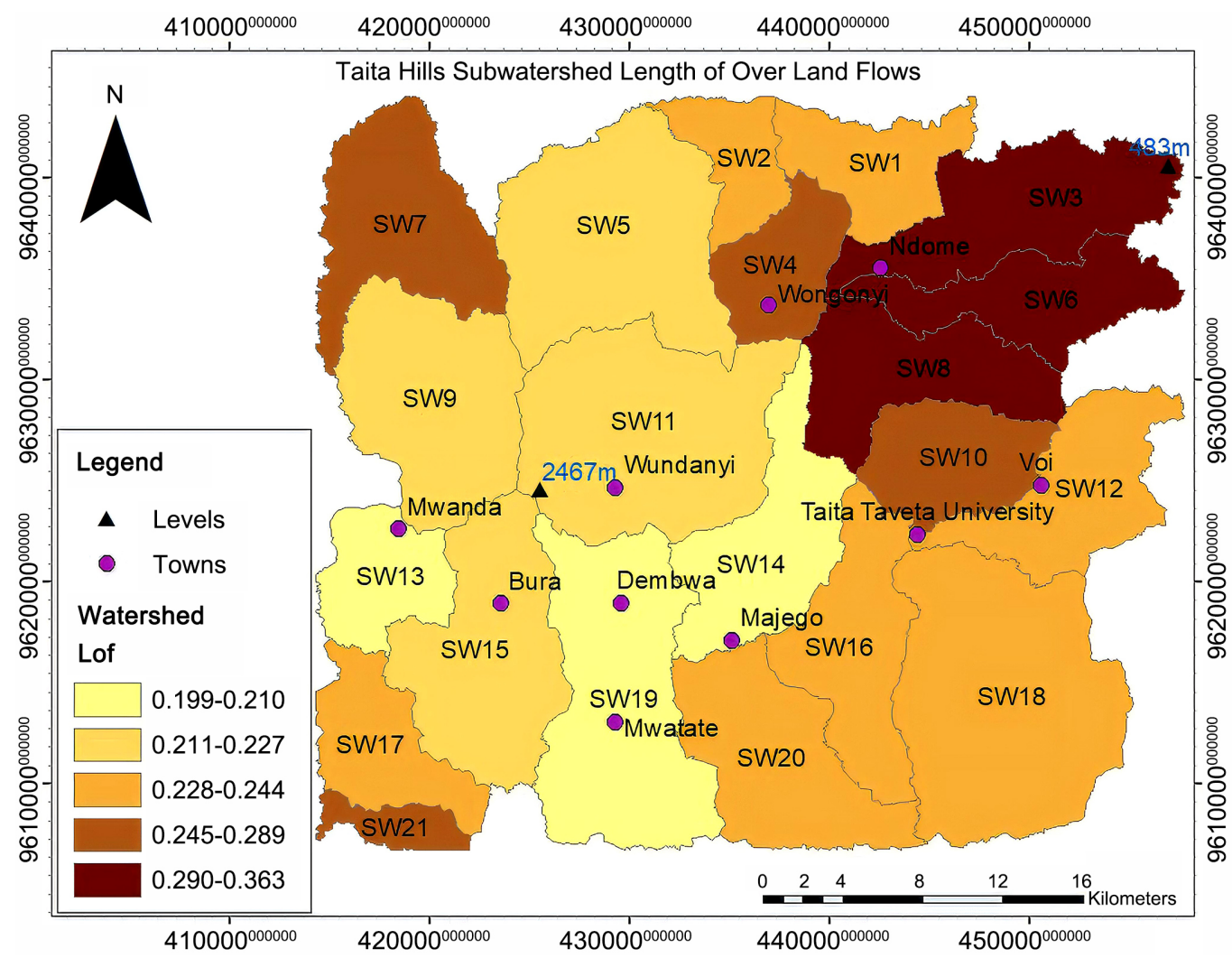

Figure 6. Length of over land flows. 


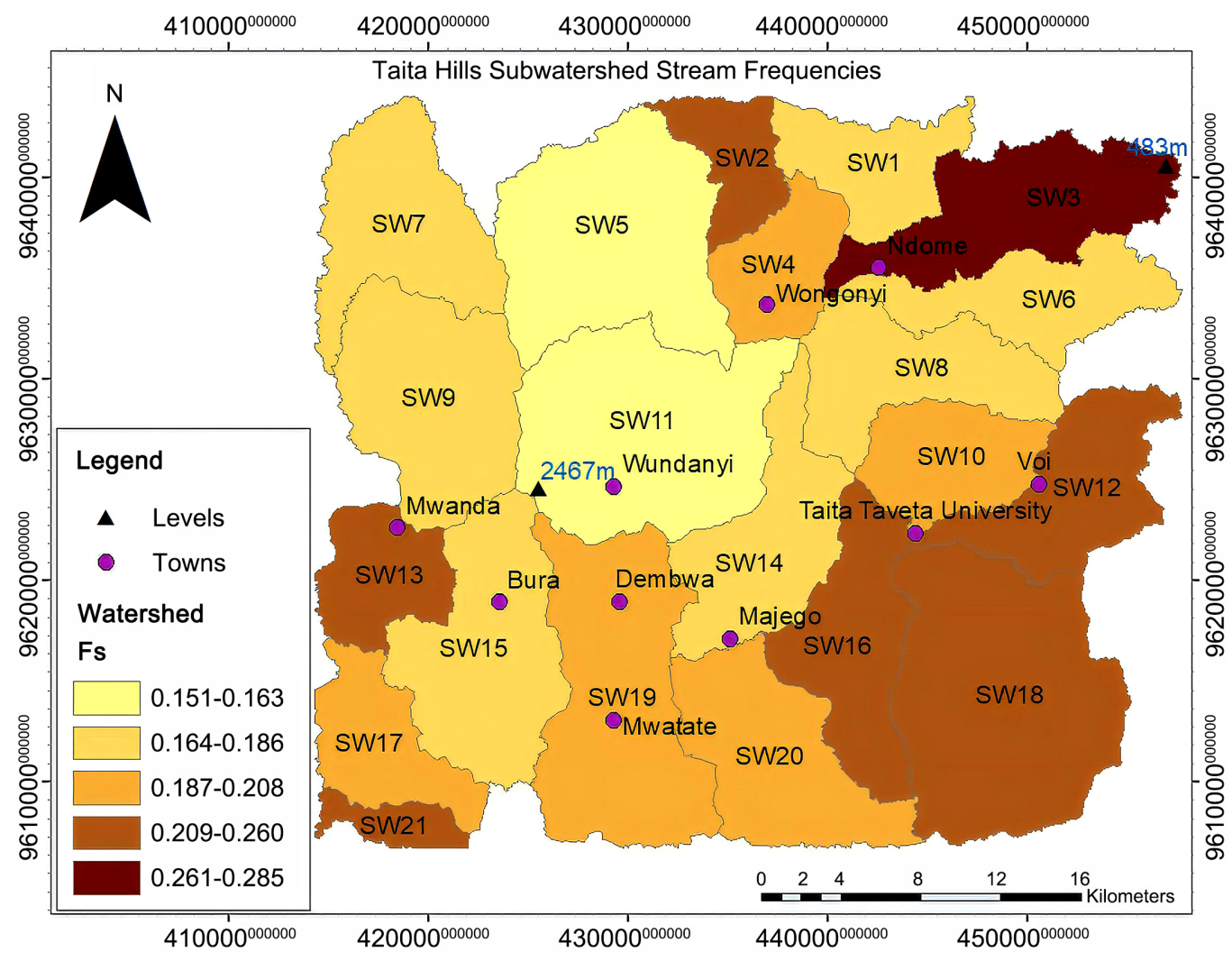

Figure 7. Stream frequencies.

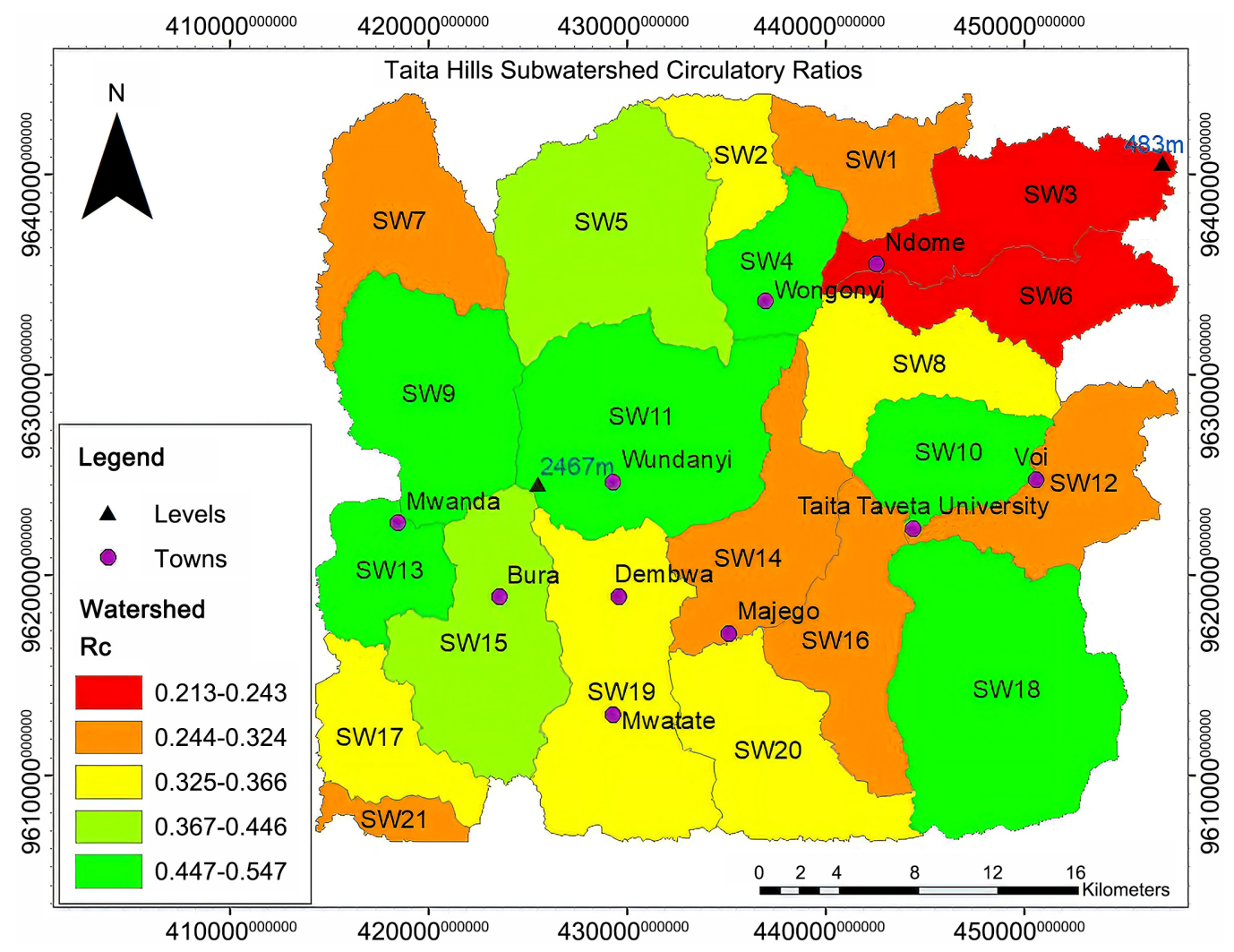

Figure 8. Circulatory ratios. 
Table 4. Shape and linear parameters.

\begin{tabular}{|c|c|c|c|c|c|c|c|c|}
\hline & $\mathrm{Rbm}$ & Fs & & $\mathrm{Dt}$ & & $\mathrm{Dd}$ & $\mathrm{Cc}$ & Bs \\
\hline SW1 & 1.67 & 0.17 & & 0.18 & & 0.49 & 1.76 & 2.85 \\
\hline SW2 & 1.67 & 0.25 & & 0.22 & & 0.46 & 1.68 & 2.71 \\
\hline SW3 & 1.10 & 0.28 & & 0.34 & & 0.64 & 2.03 & 3.09 \\
\hline SW4 & 1.25 & 0.19 & & 0.24 & & 0.54 & 1.37 & 2.81 \\
\hline SW5 & 2.25 & 0.16 & & 0.31 & & 0.43 & 1.50 & 3.25 \\
\hline SW6 & 1.33 & 0.18 & & 0.16 & & 0.73 & 2.16 & 2.94 \\
\hline sw7 & 1.70 & 0.19 & & 0.24 & & 0.54 & 1.84 & 3.07 \\
\hline SW8 & 2.75 & 0.18 & & 0.23 & & 0.63 & 1.72 & 3.01 \\
\hline SW9 & 1.67 & 0.18 & & 0.34 & & 0.44 & 1.35 & 3.15 \\
\hline SW10 & 2.33 & 0.20 & & 0.27 & & 0.58 & 1.41 & 2.88 \\
\hline SW11 & 4.63 & 0.16 & & 0.36 & & 0.45 & 1.38 & 3.29 \\
\hline SW12 & 2.38 & 0.25 & & 0.30 & & 0.46 & 1.86 & 3.00 \\
\hline SW13 & 2.33 & 0.24 & & 0.29 & & 0.41 & 1.42 & 2.81 \\
\hline SW14 & 0.00 & 0.17 & & 0.22 & & 0.42 & 1.79 & 3.03 \\
\hline SW15 & 2.05 & 0.18 & & 0.30 & & 0.45 & 1.52 & 3.15 \\
\hline SW16 & 8.00 & 0.24 & & 0.30 & & 0.49 & 1.79 & 3.02 \\
\hline SW17 & 2.08 & 0.19 & & 0.20 & & 0.47 & 1.71 & 2.86 \\
\hline SW18 & 1.88 & 0.26 & & 0.62 & & 0.48 & 1.38 & 3.35 \\
\hline SW19 & 1.60 & 0.20 & & 0.35 & & 0.40 & 1.65 & 3.25 \\
\hline SW20 & 3.67 & 0.21 & & 0.30 & & 0.47 & 1.66 & 3.08 \\
\hline \multirow[t]{2}{*}{ SW21 } & 0.00 & 0.23 & & 0.13 & & 0.52 & 1.85 & 2.45 \\
\hline & Lof & $\mathrm{Rc}$ & $R f$ & & $\operatorname{Re}$ & $\mathrm{Bh}$ & $\mathrm{Rh}$ & $\mathrm{Rn}$ \\
\hline SW1 & 0.24 & 0.32 & 0.35 & & 2.20 & 786.00 & 72.59 & 382.76 \\
\hline SW2 & 0.23 & 0.35 & 0.37 & & 2.02 & 419.00 & 48.25 & 194.74 \\
\hline SW3 & 0.32 & 0.24 & 0.32 & & 2.49 & 1250.00 & 82.82 & 800.30 \\
\hline SW4 & 0.27 & 0.53 & 0.36 & & 2.14 & 1373.00 & 135.70 & 737.07 \\
\hline SW5 & 0.22 & 0.45 & 0.31 & & 2.71 & 1167.00 & 62.31 & 506.07 \\
\hline SW6 & 0.36 & 0.21 & 0.34 & & 2.30 & 1027.00 & 83.65 & 745.23 \\
\hline SW7 & 0.27 & 0.29 & 0.33 & & 2.46 & 862.00 & 58.96 & 465.50 \\
\hline SW8 & 0.32 & 0.34 & 0.33 & & 2.40 & 1984.00 & 145.88 & 1259.40 \\
\hline SW9 & 0.22 & 0.55 & 0.32 & & 2.57 & 1303.00 & 79.69 & 579.36 \\
\hline SW10 & 0.29 & 0.50 & 0.35 & & 2.24 & 684.00 & 60.34 & 394.83 \\
\hline SW11 & 0.23 & 0.52 & 0.30 & & 2.75 & 1388.00 & 70.91 & 630.19 \\
\hline SW12 & 0.23 & 0.29 & 0.33 & & 2.37 & 757.00 & 57.00 & 350.21 \\
\hline SW13 & 0.20 & 0.49 & 0.36 & & 2.15 & 1048.00 & 103.06 & 425.87 \\
\hline SW14 & 0.21 & 0.31 & 0.33 & & 2.42 & 1014.00 & 72.48 & 426.76 \\
\hline SW15 & 0.22 & 0.44 & 0.32 & & 2.57 & 1377.00 & 83.93 & 613.82 \\
\hline SW16 & 0.24 & 0.31 & 0.33 & & 2.41 & 629.00 & 45.63 & 306.60 \\
\hline SW17 & 0.23 & 0.34 & 0.35 & & 2.20 & 449.00 & 41.11 & 209.28 \\
\hline SW18 & 0.24 & 0.52 & 0.30 & & 2.84 & 947.00 & 44.55 & 454.63 \\
\hline SW19 & 0.20 & 0.37 & 0.31 & & 2.70 & 1014.00 & 54.66 & 402.88 \\
\hline SW20 & 0.24 & 0.36 & 0.32 & & 2.48 & 461.00 & 30.96 & 217.31 \\
\hline SW21 & 0.26 & 0.29 & 0.41 & & 1.72 & 357.00 & 62.79 & 185.55 \\
\hline
\end{tabular}


Table 5. Morphometric parameter formulas.

\begin{tabular}{lcc}
\hline & Compound Parameter \\
\hline SW1 & 0.450 \\
SW3 & 0.462 \\
SW4 & 0.456 \\
SW5 & 0.460 \\
SW6 & 0.509 \\
SW7 & 0.489 \\
SW8 & 0.472 \\
SW9 & 0.629 \\
SW10 & 0.468 \\
SW11 & 0.591 \\
SW12 & 0.790 \\
SW13 & 0.530 \\
SW14 & 0.533 \\
SW15 & 0.241 \\
SW16 & 0.494 \\
SW17 & 1.155 \\
SW18 & 0.495 \\
SW19 & 0.516 \\
SW20 & 0.420 \\
SW21 & 0.676 \\
\hline
\end{tabular}

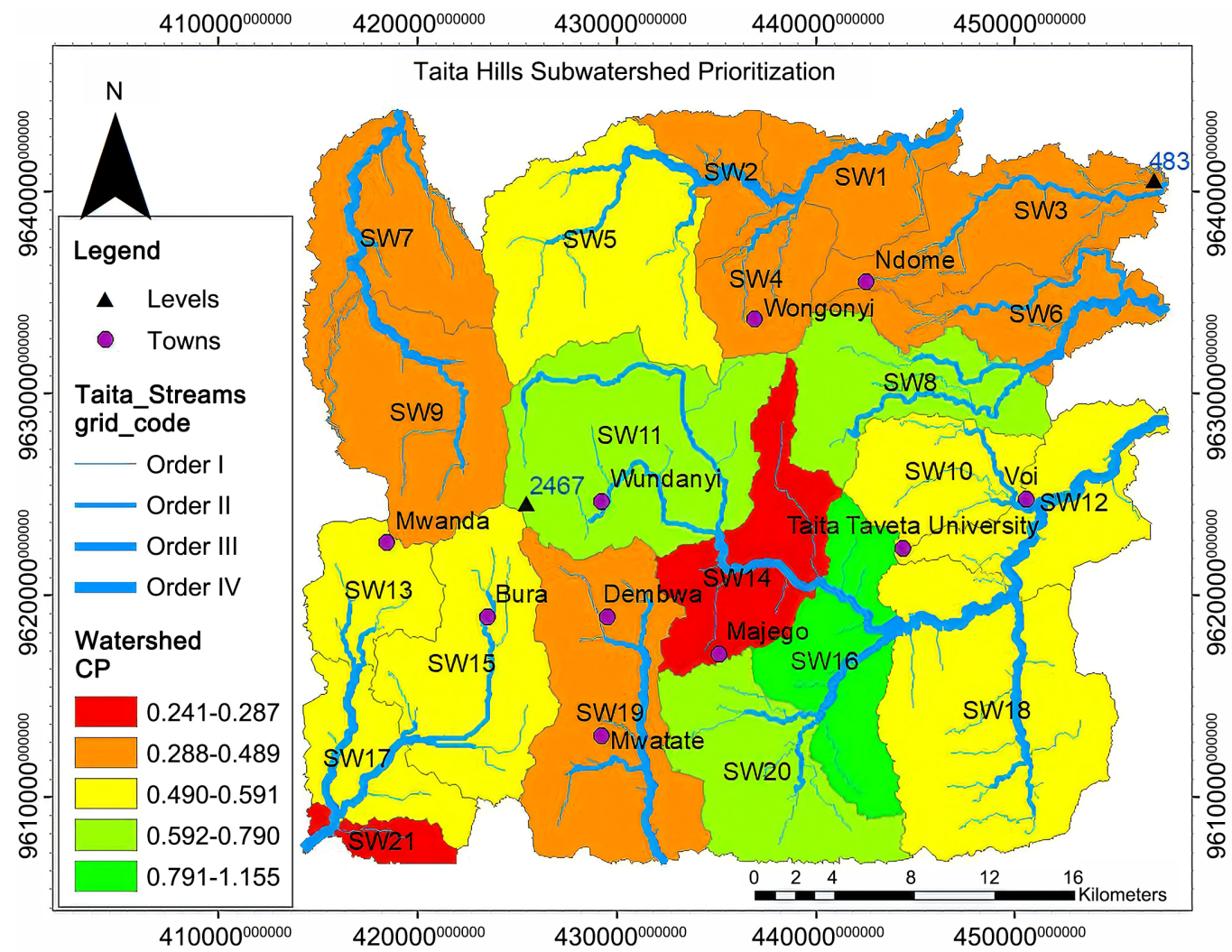

Figure 9. Sub-watershed prioritization. 
Table 6 shows the area statistics for the land covers for the two years.

Figure 10, Figure 11 are maps showing the land covers for the years 2001 and 2017. From them, the study established the changes from forest and cropland to others and Figure 12 is a result from differences of Figure 10 and Figure 11.

Table 7_shows the change statistics per sub-watersheds.

Figure 13_shows the variation of efforts needed per sub-watershed according to morphometry and change detection analysis. The output further highlights that the whole area needs for environmental protection.

Table 6. Classification by land cover of 2001 and 2017.

\begin{tabular}{|c|c|c|}
\hline Land Cover & $2001\left(\mathrm{~km}^{2}\right)$ & $2017\left(\mathrm{~km}^{2}\right)$ \\
\hline Forest & 192.2194 & 116.1953 \\
\hline Cropland & 587.8997 & 498.3389 \\
\hline Settlement & 103.1246 & 152.8757 \\
\hline Shrub-Grassland & 374.9848 & 468.0485 \\
\hline Rock Surface & 133.0503 & 115.1736 \\
\hline
\end{tabular}

Table 7. Classification by land cover of 2001 and 2017.

\begin{tabular}{|c|c|}
\hline & From Forest \& Cropland to Others \\
\hline SW15 & 31.173 \\
\hline sW5 & 31.128 \\
\hline SW11 & 29.779 \\
\hline SW19 & 28.480 \\
\hline SW17 & 20.621 \\
\hline sw9 & 17.692 \\
\hline sW7 & 14.731 \\
\hline SW13 & 14.179 \\
\hline SW12 & 13.444 \\
\hline sW8 & 13.033 \\
\hline SW14 & 12.587 \\
\hline SW10 & 10.188 \\
\hline SW20 & 9.385 \\
\hline SW18 & 8.844 \\
\hline SW3 & 7.985 \\
\hline SW4 & 7.498 \\
\hline sw2 & 7.136 \\
\hline SW21 & 6.995 \\
\hline SW1 & 5.664 \\
\hline SW16 & 5.334 \\
\hline sw6 & 5.251 \\
\hline
\end{tabular}




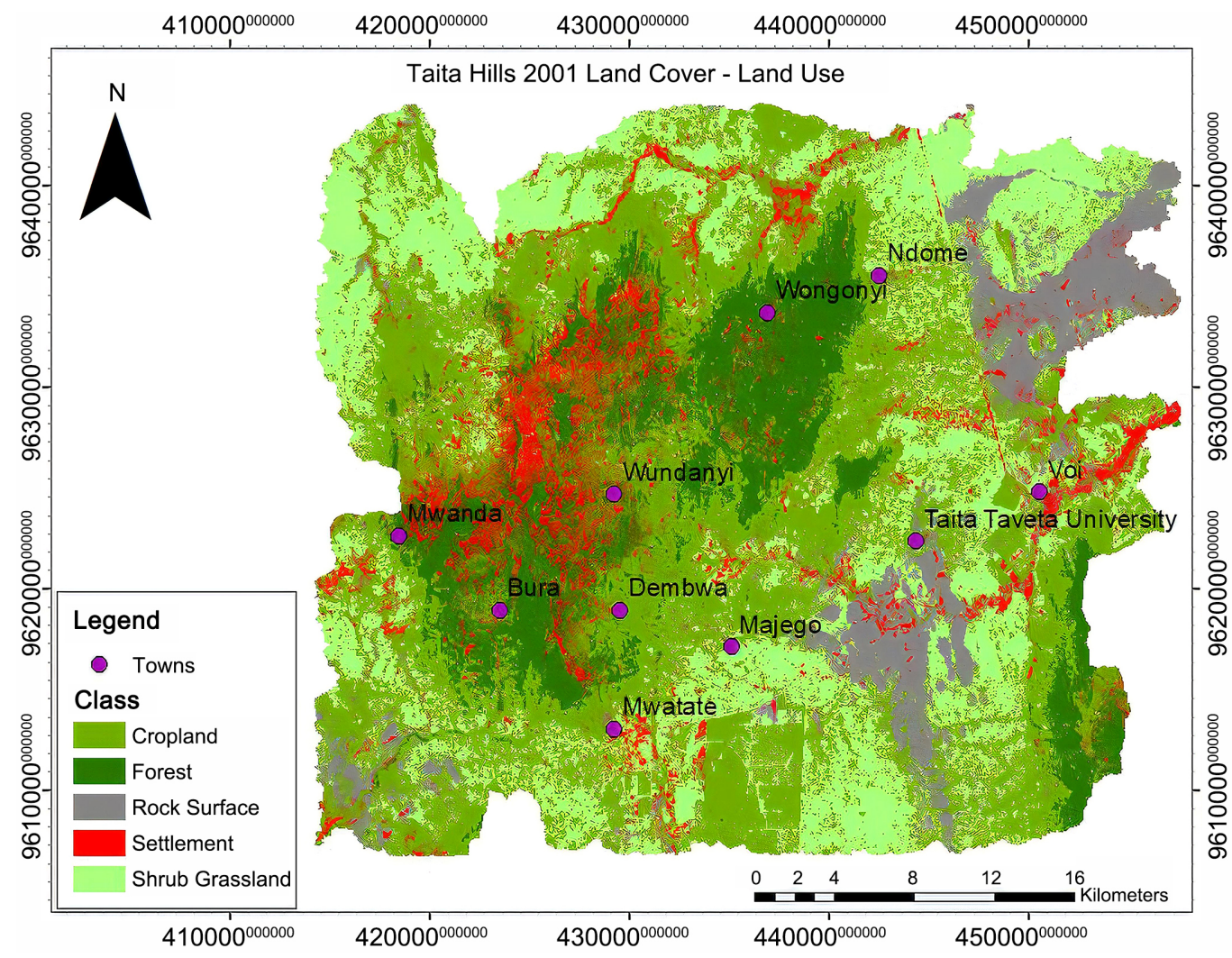

Figure 10. Land cover-land use 2001.

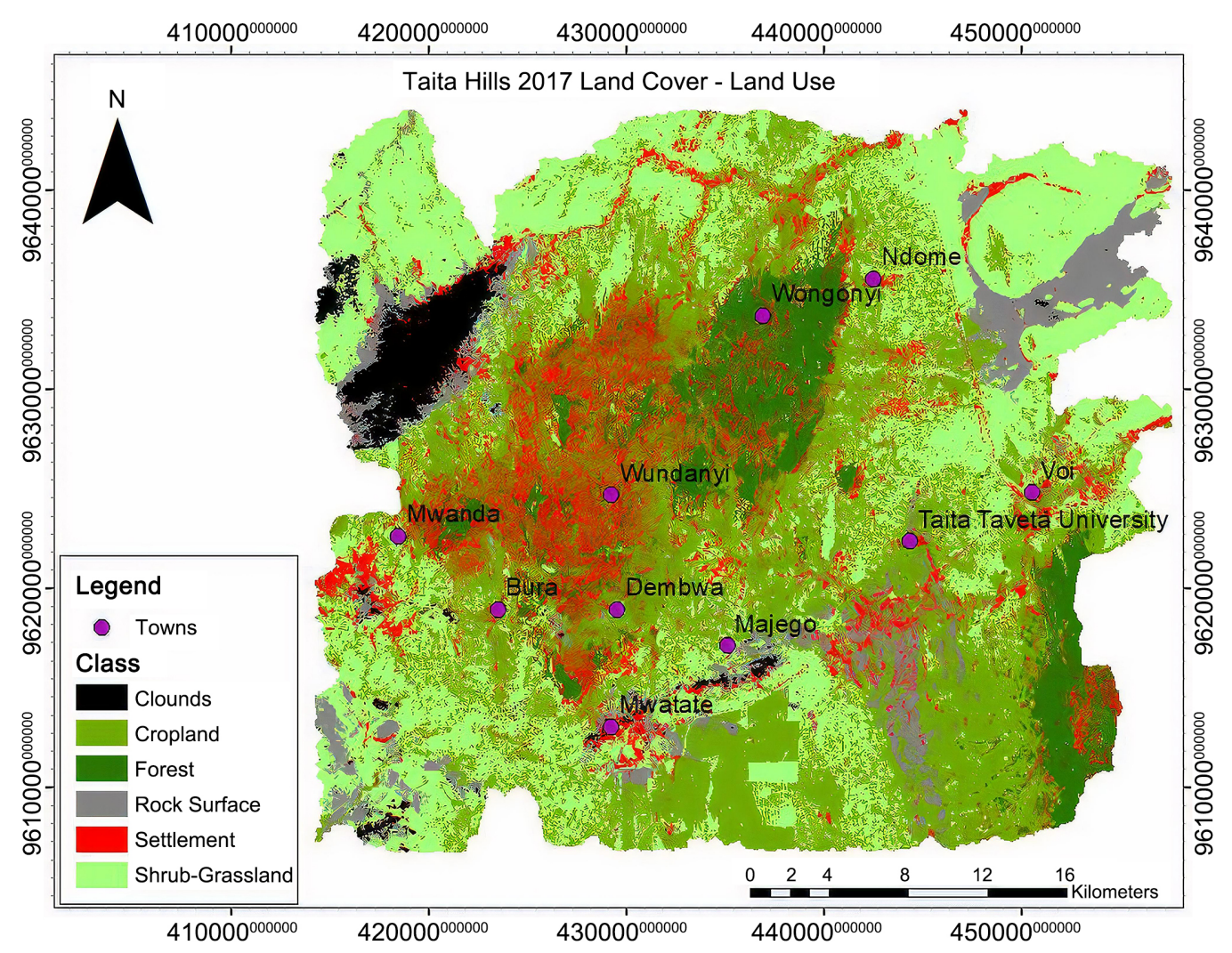

Figure 11. Land cover-land use 2017. 


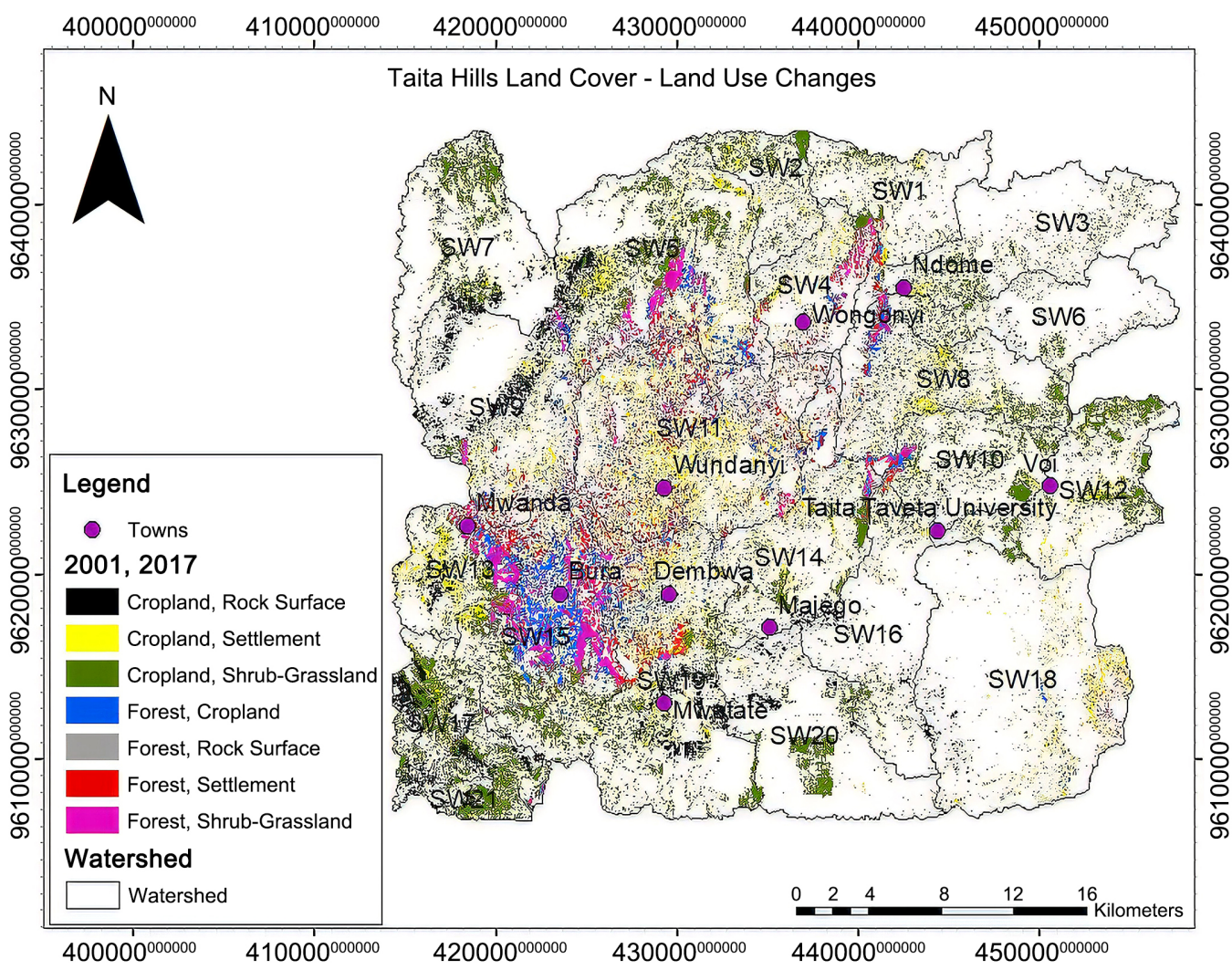

Figure 12. Land cover changes between 2001-2017.

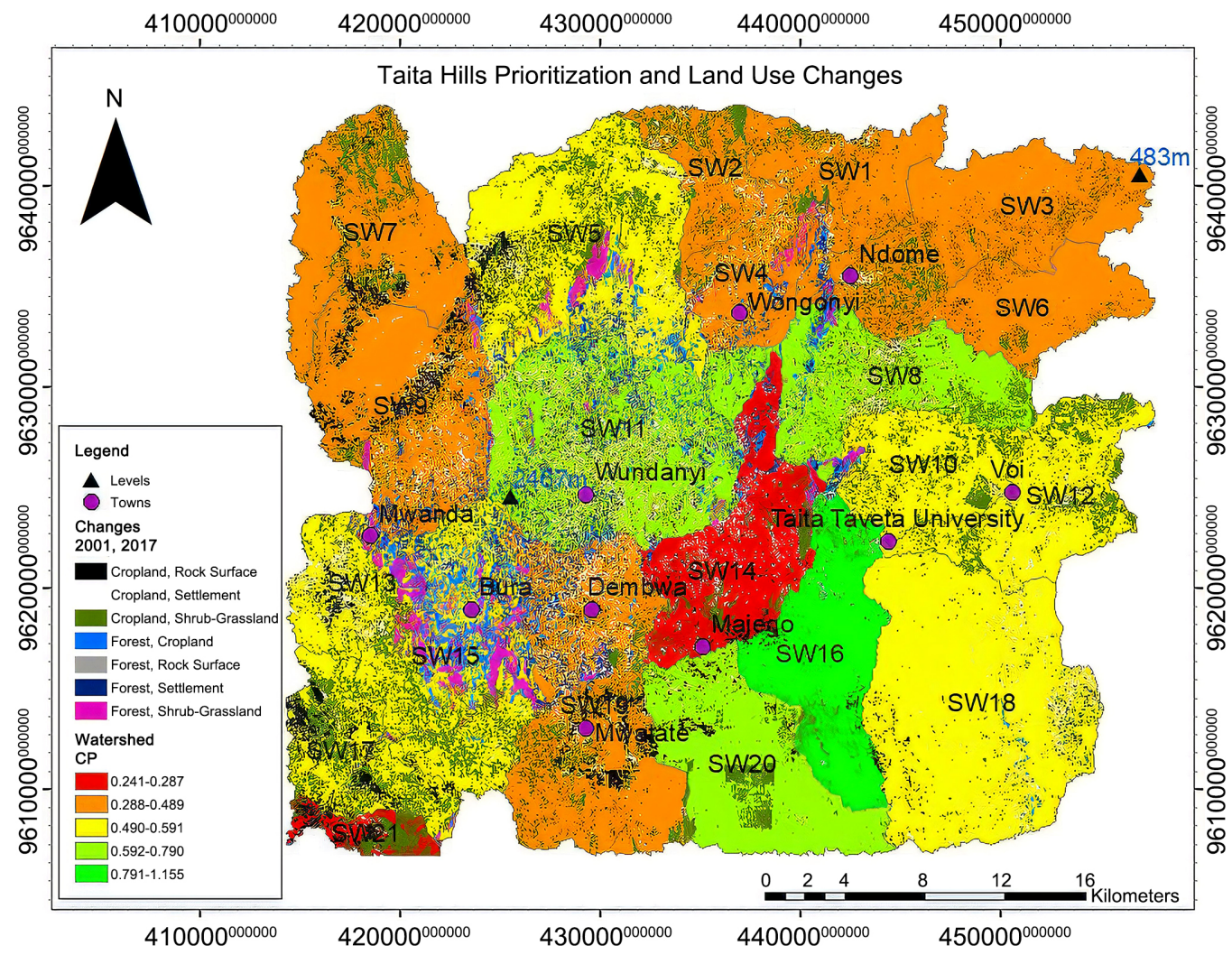

Figure 13. Land cover changes between 2001-2017 and prioritization. 


\section{Discussion}

The study involved hydrological analysis, morphometry, multi-criteria decision analysis and change detection with focus on highlighting river basins or catchments for conservation management.

According to [18] hydrological processes (peak flow, runoff, time to peak, overland flow and infiltration) are influenced by morphometric variables of the area of study. Therefore, it is important to look into morphometry to help evaluation in watershed management.

From hydrology analysis, we get a flow accumulation map that highlights the spread of rivers across the watershed and resulting sub-watersheds and as demonstrated by Figure 2 there is a general spread of rivers in the watershed. Besides, further analysis leads to computation of the morphometric parameters for each watershed from basic parameters like stream lengths, stream orders, sub-watershed areas, perimeters, number of streams, highest points and lowest points.

Morphometry in this study was vital in documenting the effects of the terrain on the hydrological processes and further used to give hierarchy in efforts required to each sub-watershed for purposes of management and conservation. PCA and WSA were used in selection of parameters to be used and combination of the parameters' effects to identify areas where the potential for harmful runoff and soil erosion are highest so that efforts could be harnessed to limit them.

The 13 parameters were reduced to 6 through PCA's selection criteria and the 6 parameters for each sub watershed are demonstrated by Figures 3-8. And for ranking to occur a WSA was done to give an equation to determine compound parameters as in Table 5 and spatially represented by Figure 9 where the red and orange sub-watersheds $(21,19,14,9,7,6,4,3,2$, and 1$)$ are more susceptible to degradation due to the landform and terrain.

The connection between land changes and morphometry has insignificantly been explored into but some studies like [17] [19] have tried to include the connection with the former using both morphometry and land use in prioritization. Land use change is a factor due to animal and human effects. Due to the LU-LC analysis as shown by Figure 12, the most changes for the period between 2001 and 2007 have happened centrally, expanding radially due to more urbanization in and around Wundanyi and surrounding towns. More forest land which is naturally the water catchment area has shifted to other land uses like cropland and settlement (Table 6 and Table 7). Potentially, there has been disruption of rainfall weather patterns due to that change.

The combination of both morphometric analysis and LU-LC analysis (Figure 13) then requires the areas of the watershed (sub watershed $3,4,7,9,19,21$ ) to need more conservation efforts as the combined effect of morphometry and land use changes have significant effects.

Sub watershed 11 is not at risk morphometrically but at risk due to land use changes but sub watershed 14 is both at risk morphometrically and due to land 
use changes (Figure 13).

\section{Conclusions}

This study analysed the Taita Hills river basin ecosystem using morphometry whereby. From the results it can be concluded that the region is a fourth order served by one major river (Voi) which flows from the centre of the region to the east with other smaller rivers flowing to different directions that serve the 21 sub-watersheds. Impervious surfaces are covering $62 \%$ of the area hence a lot of surface runoff is expected.

Morphometric Analysis, WSA and change detection results show $47 \%$ of the sub-watersheds are in high to very high risk areas with 21 and 14 as very highly risky due to morphometry and sub-watersheds 15 and 5 which are upstream that have the highest change to degraded vegetation (Shrub-Grassland, Settlement and Rock Surface).

With both morphometric analysis and change detection combined the results visually show sub-watersheds $3,4,7,9,19$, and 21 as the risky areas with runoff and land cover change.

There is a need to establish detailed continuous monitoring of land use changes in detail together with any major changes in elevation within a region so that efforts of conservation are done when little damage has occurred or prediction and avert degradation.

Results of this study point towards the significant effects of landform on the river basin ecosystem and can be used to isolate regions for specific focus hence the governments and non-governmental bodies should consider setting aside funds for reliable water catchment management.

Further research on river basin management can still be done to automize the whole process of watershed prioritization considering both land use and morphometry.

\section{Conflicts of Interest}

The authors declare no conflicts of interest regarding the publication of this paper.

\section{References}

[1] Farhan, Y., Anbar, A., Al-Shaikh, N., Almohammad, H., Alshawamreh, S., Barghouthi, M. and Barghouthi, M. (2018) Prioritization of Sub-Watersheds in a Large Semi-Arid Drainage Basin (Southern Jordan) Using Morphometric Analysis, GIS, and Multivariate Statistics. Agricultural Sciences, 9, 437-468. https://doi.org/10.4236/as.2018.94031

[2] United Nations Conference on Environment and Development (1992) Agenda 21, UNCED, Geneva.

[3] Helldén, U. (2008) A Coupled Human-Environment Model for Desertificatio Simulation and Impact Studies. Global and Planetary Change, 64, 158-168. https://doi.org/10.1016/j.gloplacha.2008.09.004 
[4] UNDP (2019) Goal 15: Life on Land. UNDP.

https://www.undp.org/content/undp/en/home/sustainable-development-goals/goal15-life-on-land.html

[5] Altaf, F., Meraj, G. and Romshoo, S.A. (2013) Morphometric Analysis to Infer Hydrological Behaviour of Lidder Watershed, Western Himalaya, India. Geography Journal, 2013, Article ID: 178021. https://doi.org/10.1155/2013/178021

[6] Strahler, A.N. (1957) Quantitative Analysis of Watershed Geomorphology. Eos, Transactions American Geophysical Union, 38, 913-920. https://doi.org/10.1029/TR038i006p00913

[7] Aher, P.D., Adinarayana, J. and Gorantiwar, S.D. (2014) Quantification of Morphometric Characterization and Prioritization for Management Planning in Semi-Arid Tropics of India: A Remote Sensing and GIS Approach. Journal of Hydrology, 511, 850-860. https://doi.org/10.1016/j.jhydrol.2014.02.028

[8] Malik, A., Kumar, A. and Kandpal, H. (2019) Morphometric Analysis and Prioritization of Sub-Watersheds in a Hilly Watershed Using Weighted Sum Approach. Arabian Journal of Geosciences, 12, 118.

https://doi.org/10.1007/s12517-019-4310-7

[9] Horton, R.E. (1945) Erosional Development of Streams and Their Drainage Basins; Hydrophysical Approach to Quantitative Morphology. Geological Society of America Bulletin, 56, 275-370. https://doi.org/10.1130/0016-7606(1945)56[275:EDOSAT]2.0.CO;2

[10] Horton, R.E. (1932) Drainage-Basin Characteristics. Eos, Transactions American Geophysical Union, 13, 350-361. https://doi.org/10.1029/TR013i001p00350

[11] Miller, V.C. (1953) A Quantitative Geomorphic Study of Drainage Basin Characteristics on the Clinch Mountain Area, Virginia and Tennessee. Technical Report, Project No. NR 389-402.

[12] Schumm, S.A. (1956) Evolution of Drainage Systems and Slopes in Badlands at Perth Amboy, New Jersey. Geological Society of America Bulletin, 67, 597-646. https://doi.org/10.1130/0016-7606(1956)67[597:EODSAS]2.0.CO;2

[13] Gravelius, H. (1914) Morphometry of Drainage Bassins. Elsevier, Amsterdan.

[14] Strahler, A.N. (1964) Part II. Quantitative Geomorphology of Drainage Basins and Channel Networks. In: Chow, Y.T., Ed., Handbook of Applied Hydrology, McGraw-Hill, New York, 4-39.

[15] Kadam, A.K., Jaweed, T.H., Kale, S.S., Umrikar, B.N. and Sankhua, R.N. (2019) Identification of Erosion-Prone Areas Using Modified Morphometric Prioritization Method And Sediment Production Rate: A Remote Sensing and GIS Approach. Geomatics, Natural Hazards and Risk, 10, 986-1006.

https://doi.org/10.1080/19475705.2018.1555189

[16] Dar, R.A., Chandra, R. and Romshoo, S.A. (2013) Morphotectonic and Lithostratigraphic Analysis of Intermontane Karewa Basin of Kashmir Himalayas, India. Journal of Mountain Science, 10, 1-15. https://doi.org/10.1007/s11629-013-2494-y

[17] Mohd Iqbal, H.S. and Sajjad, H. (2014) Watershed Prioritization Using Morphometric and Land Use/Land Cover Parameters of Dudhganga Catchment Kashmir Valley India using Spatial Technology. Journal of Geophysics \& Remote Sensing, 3, 1-12. https://doi.org/10.4172/2169-0049.1000115

[18] Samal, D.R., Gedam, S.S. and Nagarajan, R. (2015) GIS Based Drainage Morphometry and Its Influence on Hydrology in Parts of Western Ghats region, Maharashtra, India. Geocarto International, 30, 755-778. 
https://doi.org/10.1080/10106049.2014.978903

[19] Biswas, R. and Chakraborty, S. (2016) Watershed Prioritization Based on Geo-Morphometry and Land Use Parameters-An Approach to Watershed Development Using Remote Sensing and GIS, Neora watershed, Darjeeling and Jalpaiguri districts, West Bengal, India. IOSR Journal of Applied Geology and Geophysics, 4 , 36-48. 